\title{
ANALISIS YURIDIS TERHADAP TINDAKAN ABORSI DALAM PERSPEKTIF HUKUM PIDANA INDONESIA (Studi Komparatif; Undang-Undang Kesehatan, KUHP dan HAM)
}

\section{YURIDICAL ANALYSIS OF ABORTION ACTION IN INDONESIA CRIMINAL LAW PERSPECTIVES \\ (A Comparative Study; Penal Health, Penal Code and Human Rights)}

\author{
Rustam \\ Program Studi Ilmu Huku m Fakultas Hukum \\ Universitas Riau Kepulauan, Batam, Indonesia \\ fendy harjo@yahoo.com
}

\begin{abstract}
Abstrak
Tujuan dari penelitian ini adalah untuk melihat tinjaun yuridis terhadap tindakan aborsi yang ditinjau dari Undang-Undang No.36 Tahun 2009, Kitab Undang-Undang Hukum Pidana (KUHP), hubungan antara Kitab Undang-Undang Hukum Pidana (KUHP) dan UU No. 36 Tahun 2009serta perbandingan pandangan (Perspektif) terhadap aborsi antara UU No.36 Tahun 2009 Tentang Kesehatan, KUHP dan HAM. Berdasarkan aturan KUHP dan HAM aborsi dilarang sedangkan menurut Undang-Undang No.36 Tahun 2009, aborsi diperbolehkan dengan syarat tertentu. Pendekatan yang digunakan adalah pendekatan analis is yuridis. Perbedaan aturan tentang aborsi yakni antara Undang-Undang No.36 Tahun 2009, Kitab Undang-Undang Hukum Pidana (KUHP) dan Hak Azazi Manusia ditengahi oleh asas lex posteriori derogat legi priori yang me mbuat gagasan baru tentang aborsi yakni pada kedaruratan medis yakni provokatus medicalis. Sedangkan abortus provocatus, berdasarkan pandanga ketiga aturan tersebut adalah merupakan tindakan pidana yang dilarang, serta di anggap sebagai pelanggaran terhadap hak azazi manusia.
\end{abstract}

Kata Kunci; Aborsi, Hukum Pidana, KUHP, HAM

\section{Abstract}

The purpose of this study is to determine at the legal review of abortion actions reviewed from Law No.36 of 2009, Penal Code, the relationship between the , Penal Code and Law No, 36 of 2009 and comparison of perspective on Abortion action among Law no. 36 in 2009 on Health, Penal Code and Human Rights. Based on Penal Code and Human Rights, abortion is prohibited in Indonesia but based on the Law No.36 of 2009 stated that abortioncould be done with certain conditions. The approach used was the juridical analysis approach. Differences abortion regulation lawsbased on the Law No.36 of 2009, Penal Code and Human Rights were mediated by the principle of "lex posteriori derogat legion priori" which made an issue on abortion regulation lawsonly in medical emergency namely" provokatus medicalis". Meanwhile "forabortus provocatus", based on the threelaws'views, is a prohibited action and considered as a violation of human rights.

Keywords; Abortion, Criminal Law, Penal Code, Human Rights 


\section{PENDAHULUAN}

Aborsi merupakan fenomena sosial yang semakin hari semakin memprihatin kan. Keprihatinan itu bukan tanpaalasan,karena sejauh ini perilaku pengguguran kandungan banyak menimbulkan efek negat if baik untuk diri pelaku mapun pada masyarakat luas. Hal ini disebabkan karena aborsi menyangkut norma moral serta hukum suatu kehidupan bangsa. Aborsi merupakan cara yang paling sering digunakan mengakhri kehamilan yang tidak diinginkan, tetapi juga cara yang paling berbahaya. Aborsi menurut terjadinya dibedakan atas Abortus Spontan, yaitu aborsi yang terjadi dengan sendirinya tanpa disengaja atau dengan tidak didahului faktor-faktor mekanis atau medisialis, semata-mata disebabkan oleh faktor alamiah, dan abortus provokatus yaitu aborsi yang disengaja tanpa ind ikasi medis, baik dengan obat-obatan maupun dengan alat-alat. Aborsi jenis ini dibagi lagi menjadi Abortus medisinalis (abortus therapeuticus) merupakan aborsi karena tindakan kita sendiri, dengan alasan bila kehamilan dilanjutkan, dapat membahayakan jiwa ibu (berdasarkan indikasi medis). Biasanya perlu mendapat persetujuan 2 sampai 3 tim dokter ahli (Notoatmodjo, 2010:136).

Menurut Rukmin (2002; 10), aborsi atau bisa dikenal dengan Abortus provocatusberasal dari kata abortus yang artinya gugur kandungan/keguguran”. Pengertian aborsi atau Abortus Provocatus adalah penghentian atau pengeluaran hasil kehamilan dari rahim sebelum waktunya. Dengan kata lain pengeluaran itu dimaksudkan bahwa keluarnya janin disengaja dengan campur tangan manusia, baik melalui cara mekanik, obat atau cara lainnya (Kusmaryanto, 2001: 203). Abortus Provocatus merupakan istilah lain yang secara resmi dipakai dalam kalangan kedokteran dan hukum. Dalam pengertian medis Aborsi (baik keguguran maupun pengguguran kandungan) berarti terhentinya kehamilan yang terjadi di antara saat tertanamnya sel telur yang sudah (blastosit) dirahim sampai kehamilan 28 minggu. Batas 28 minggu dihitung sejak haid terakhir itu diambil karena sebelum 28 minggu, janin belum dapat hidup (variabel di luar rahim) (Chandra, 2006;1).

Hadirnya Undang-Undang Republik Indonesia No.36 Tahun. 2009 Tentang Kesehatan, juga mengupas masalah abortus, yaitu pada pasal 75 ayat 1 "setiap orang dilarang melakukan aborsi " namun dikecualikan dalam ayat 2,yaitu :

a. Indikasike daruratanmed is yangdideteksisejakdinikehamilanbaik yangmengancam nyawaibudan/ataujaninyangyangmenderita cacat bawaan maupun yang tidak dapat diperbaiki sehingga menyulitkan bayi tersebut hidup diluar kandungan ,atau

b. Kehamilan akibat perkosaan. 


\section{METODOLOGI}

Analisis adalah kegiatan merangkum sejumlah data besar yang masih mentah kemudian mengelompokan atau memisahkan komponen-komponen serta bagian-bagian yang relevan untuk kemudian mengkaitkan data yang dihimpun untuk menjawab permasalah. Analisis merupakan usaha untuk menggambarkan pola-pola secara konsisten dalam data sehingga hasil analisis dapat dipelajari dan diterjemahkan dan memiliki arti (Surayin, 200: 10). Sedangkan yuridis adalah hal yang diakui oleh hukum, didasarkan oleh hukum dan hal yang membentuk keteraturan serta memiliki efek terhadap pelanggarannya (media informasill.com), yuridis merupakan suatu kaidah yang dianggap hukum atau dimata hukum dibenarkan keberlakuannya, baik yang berupa peraturan-peraturan, kebiasaan, etika bahkan moral yang menjadi dasar penilaiannya.

Dalam penelitian ini yang dimaksud oleh penulis sebagai analisi yuridis adalah kegiatan untuk mencari dan memecah komponen-komponen dari suatu permasalahan untuk dikaji lebih dalam serta kemudian menghubungkannya dengan hukum, kaidah hukum serta norma hukum yang berlaku sebagai pemecahan permasalahannya. Kegiatan analisis yuridis adalah mengumpulkan hukum dan dasar lainnya yang relevan untuk kemudian mengambil kesimpulan sebagai jalan keluar atau jawaban atas permasalahan (media informasill.com) Tujuan kegiatan analisis yuridis yaitu untuk membentuk pola pikir dalam pemecahan suatu permasalahan yang sesuai dengan hukum khususnya mengenai masalah aborsi.

\section{PEMBAHASAN}

\section{Aborsi Provokatus CriminalisDintinjau Dari Undang-Undang No.36 Tahun 2009 Tentang Kesehatan}

Ketika berbicara mengenai aborsi tentu erat kaitannya dengan tenaga kesehatan terutama dokter selakuyangmelakukan aborsi terhadap pasiennya. Sebelum menerima gelar dokter akan mengucapkan lafal sumpahnya yang berbunyi;

"saya akan menghormati hidup insani mulai dari saat pembuahan" ada yang menyebutkan bahwa sejak 1983 lafal tersebut telah diubah oleh World Medical Associaltion (WMA) menjadi "sejak kehidupan itu mulai"

Tetapi perubahan ini belum atau tepatnya tidak diberlakukan di Indonesia sampai pada saat ini, sehingga lafal Sumpah Dokter kita masih tetap seperti 1948 (Achadiat, 2006; 164) Setiap dokter harus senantiasa mengingat akan kewajiban melindungi hidup mahluk insani dalam buku Kode Etik Kedokteran Indonesia yang diterbitkan oleh Ikatan Dokter Indo nesia, 
disebutkan dalam bagian penjelasan Pasal 10 yakni: Seorang dokter tidak boleh melakukan abortus provocatus dan euthanisia. Pada bagian lain dari penjelasan itu juga disebutkan bahwa aborsi provokatus dapat dibenarkan sebagai pengobatan, apabila merupakan satusatunya jalan untuk menolong jiwa ibu daribahaya maut (aborsi provokatus therapeuticus).

Jadi etika kodokteran send iri memang sudah tidak mengizinkan para dokterdi Indonesia untukmelakukan aborsi kecuali atas indikasi kedaruratan medis dan rumusan kode etik kedokteran indonesia atau disingkat dengan Kodeki inilah yang berlaku di Indonesia. Singkatnya, perbuatan aborsi merupakan pelanggaran terhadap Sumpah Dokter dan Kodeki kecuali atas indikasi kedaruratan medis Rumusan pasal 10 Kodeki beserta penjelasanya inilah yang nampak menjiwai Pasal 75 UU No. 36 Tahun 2009 tentang Kesehatan, yakni:

(1) Setiap orang dilarang melakukan aborsi

(2) Sebagaimana dimaksud pada ayat (1) dapat dikecualikan berdasarkan:

a. Indikasi kedaruratan medis yang dideteksi sejak usia dini kehamilan, baik yang mengancam nyawa ibu dan/atau janin, yang menderita penyakit genetik berat dan/atau cacat bawaan, maupun yang tidak dapat diperbaiki sehingga menyulitkan bayi tersebut hidup diluar kandungan

b. Kehamilan akibat perkosaan yang dapat menyebabkan trauma psikologis bagi korban perkosan

(3) Tindakan sebagaimana dimaksud pada ayat (2) hanya dapat dilakukan setelah melalui konseling pra tindakan dan diakhiri dengan konseling pasca tindakan yang dilakukan konselor yang berkompeten dan berwenang.

(4) Ketentuan lebih lanjut mengenai indikasi kedaruratan medis dan perkosaan, sebagaimana dimaksud pada ayat (2) dan ayat (3) diatur dalam Peraturan Pemerintah.

Selain itu juga dimuat mengenai syarat dan ketentuan dari pelaksanaan aborsi dalam Pasal 76 UU No. 36 Tahun 2009 yakni:

a. Sebelum kehamilan berumur 6 (enam) minggu dihitung dari hari pertama haid terakhir, kecuali dalam hal kedaruratan medis

b. Oleh tenaga kesehatan yang memiliki keterampilan dan kewenangan yang memiliki sertifikat yang ditetapakan oleh mentri

c. Dengan persetujuan ibu hamil yang bersangkutand. Dengan izin suami, kecuali korban perkosaan

d. Penyedia layanan kesehatan yang memenuhi syarat yang ditetapkan oleh menteri.

Ketentuan Pasal 75 dan 76 UU No. 36 Tahun 2009 sejalan dengan Kode Etik Kedokteran Indonesia yang telah dikuatkan Permenkes dan itu berarti ada konsekuensi hukum apabila terjadi pelanggaran. Namum perkembangan yang terjadi selama ini, tindak pidana aborsi seolah-olah menjadi legal/sah karena alasan-alasan lain, seperti: Rasa kemanusiaan, ingin "menolong" pasien, menghindarkan konsekuensi aborsi oleh dukun dan lain sebagainya. 
Sumpah Dokter dan Kode etik kedokteran dengan tegas dan jelas menyebutkan bahwa tindakan seorang dokter melakukan aborsi adalah bertentangan dengan sumpah dan kode etik kedokteran. Pengecualiaanya adalah jika kehamilan itu mengancam jiwa si ibu, dengan akibat samping kandungannya yang akan mengalami keguguran oleh karena itu, moralitas dan etika kedokteran sebenarnya memang tidak membenarkan aborsi sebagai tujuan suatu tindakan. Aborsi hanya bisa dilakukan seandainya tidak ada jalan lain lagi untuk meyelamatkan jiwa si ibu. Itu pun dilakukan setelah memenuhi syarat tertentu, seperti pertimbangan paling sedikit dari dua orang ahli. Selain itu harus dilakukan di sarana kesehatan yang memadai, baik personil maupun peralatannya, selanjutnya, perlu diketahui bahwa lafal sumpah dokter dan Kodeki itu ternyata telah menjadi Permenkes.

Banyak yang mengira bahwa UU Kesehatan seakan memberikan keleluasaan untuk tindak aborsi, padahal sebenarya tidak demikian adanya. Dalam UU tersebut dengan jelas melarang aborsi kecuali karena indikasi kedaruratan medis dan korban perkosaan, yang juga ditetapkan tentang kehamilan yang boleh diaborsi, skaligus syarat-syarat yang harus dipenuhi. Bagi yang tidak memenuhi ketentuan-ketentuan Pasal 75 dan 76 UU Kesehatan, ditetapakan sanksi pidana yang berat.

Bagaimana jika aborsi dilakukan tanpa memenuhi syarat-syarat yang ditetapkan pada Pasal 75 dan 76 UU Kesehatan telah diatur dalam Pasal 194 UU Kesehatan yakni:

"setiap orang yang dengan sengaja melakukan aborsi tidak sesuai dengan ketentuan sebagaimana dikmaksud dalam Pasl 75 ayat (2)dipidana dengan pidana penjara paling lama 10 (sepuluh) tahun dan denda paling banyak Rp. 1.000.000.000.000 (satu milyar)".

Tidak dapat dipungkiri lagi bahwa sebagian besar aborsi dilakukan kalangan dokter dan tenaga medis lainnya. Aborsi merupakan masalah yang sangat rumit dan pelik, menyangkut hampir semua sektor kehidupan masyarakat. Namum, tidak pantas pula jika dokter kemudian mengambil "jalan pintas" dengan mengabaikan dan mengingkari moralitas serta etika profesi kedokteran, dan terutama melanggar hukum dan dalam mengantisipasi masalah aborsi.

Penghentian kehamilan merupakan suatu masalah yang serius dan tidak dapat dibiarkan berlarut-larut, sehingga dalam hal tersebut hanya dapat diluluskan apabila wanita itu berada dalam suasana bahaya yang tidak dapat teratasi (Bertens, 2010; 56).Dengan demikian perlu adanya pertimbangan-pertimbangan seksama agar kedua kepentingan yang sama beratnya diletakkakan pada profersi yang layak Disamping itu perlu diambil keputusan 
yang meletakkan tanggung jawab wanita yang hamil, dokter maupun orang-orang yang terlibat langsung agar mengindahkan baik titik tolak yang satu maupun yang lainnya.

Jadi dalam Undang-undang No. 36 Tahun 2009 tentang Kesehatan ini menjamin, bahwa keadaan darurat wanita harus diinformasikan dan kemungkinan- kemungkinan selain aborsi perlu diberitahukan dan dokter harus yakin bahwa wanita tersebut telah mengajukan permohonan penghentian kehamilan sukarela dan mempertahankannya tanpa paksa.

\section{Aborsi Provokatus Medicalis Ditinjau Dari Undang-Undang Kesehatan No. 36 Tahun 2009}

Dalam Undang-undang No. 36 Tahun 2009 tentang kesehatan ditegaskan dengan jelas bahwa aborsi adalah perbuatan yang dilarang. Namum aborsi dapat dibenarkan untuk dilaksanakan tetapi karena adanya indikasi kedaruratan medis guna menyelamatkan nyawa ibu dan aborsi yang dilakukan oleh korban perkosaan.

Jika ditinjau dari segi medis, tidak ada batasan pasti kapan kandungan bisa digugurkan. Kandungan seorang perempuan bisa digugurkan kapan saja sepanjang ada indikasi medis untuk aborsi namum tentunya semakin lama umur kandungan resiko keselamatan ibu juga semakin kecil. Misalnya jika diketahui anak yang akan lahir mengalami cacat berat atau si ibu menderita penyakit jantung yang akan sangat berbahaya sekali untuk keselamatan jiwanya pada saat melahirkan nanti, sekalipun janin itu sudah berusia lima bulan atau enam bulan, pertimbangan ini semata-mata karena kedaruratan medis. Dalam dunia medis aborsi provokatus medicinalis dibedakan menjadi 3 (tiga) yaitu:

1. Aborsi pada triwulan pertama sampai dengan 12 minggu. pada kehamilan sampai batas 7 minggu pengeluaran isi rahim dilakukan dengan kuret tajam, agar ovum kecil tidak tertinggal, maka ovum uteri dikerok seluruhnya. Apabila kehamilan melebihi 6 sampai 7 minggu digunakan kuret tumpul sebesar yang dapat dimasukkan. Setelah hasil konsepsi sebagian besar lepas dari dinding uterus maka hasil tersebut dapat dikeluarkan dengan cunam abortuis dan kemudian dilakukan kerokan hati-hati dengan kuret tajam yang cukup besar, apabila diperlukan dimasukkan tampon kedalam uteri dan vagina yang akan dikeluarkan esok harinya.

2. Aborsi provokatus kehamilan 12 sampai 16 minggu. Aborsi dilakukan dengan menggunakan perpaduan antara dilatasi, kuret dan pengisapan. Bahaya dari cara ini adalah terbentuknya luka-luka yang menimbulkan pendarahan.

3. Aborsi pada triwulan kedua (Kehamilan sampai 16 minggu), dilakukan dengan menimbulkan kontraksi-kontraksi uterus supaya janin dan plasenta dapat dilahirkan secara spontan. Cara yang dilakukan adalah dengan melakukan esantasi (pembiusan)

Biasanya dalam praktek kedokteran, pertimbangan utama tetap pada diri ibu. Dengan demikian nyawanya lebih berharga daripada nyawa anak yang dikandungnya. Meski 
demikian, tidak menutup kemungkinan dokter berpendapat sebaliknya dengan tetap mengacu pada pasien atau keluarganya. Bahkan seringkali dokter harus mengambil jalan tengah, berusaha menyelamatkan keduanya, ibu dan anaknya.

Kedaruratan medis akan berubah-ubah menurut perkembangan ilmu kedokteran. Jadi tidak dibenarkan melakukan aborsi atas indikasi tidak adanya biaya untuk membesarkan anak, kehamilan diluar nikah, tidak menginginkan jeniskelamin bayi yang dikandung, karena anak diketahui jika dilahirkan akan cacat dan alasan yang lain sebenarnya sama sekali membahayan sang ibu. Dr. dr. Budi Santoso, Sp.OG mengatakan dokter obstetri dan ginekologi umumnya menggunakan pandangan yang arif dalam masalah aborsi. Menurut dr. Budi, dalam segi medis, aborsi diperbolehkan asalkan hal itu memang diperlukan untuk menyelamatkan nyawa ibu dan janin. Hal tersebut disebut sebagai aborsi medicinalis dan diatur dalam Deklarasi Oslo, dengan ketentuan harus ada indikasi medis dan diputuskan oleh dua orang dokter yang kompeten di bidangnya.

Dalam Pedoman Etik Obsetri dan Ginekologi (POGI) juga disebutkan. "Safe abortion dilakukan hanya sebagai exit emergency atau pintu keluar darurat," dimana aborsi yang dimaksudkan adalah aborsi yang memang dilakukan sebagai upaya dan jalan terakhir demi keselamatan nyawa ibu dan janin. Keadaan darurat yang diperbolehkan adalah kegagalan kontrasepsi, korban perkosaan, korban incest, gangguan jiwa berat, gangguan pada janin (down synd rome) atau cacat bawaan, terinfeksi HIV/AIDS, atau tidak sehat secara fisik, mental, dan ekonomi. Meskipun aborsi diperbolehkan karena indikasi medis tetapi terdapat syarat-syarat yang harus dipenuhi oleh pasien yang akan melakukan aborsi yang termuat dalam Pasal 76 yaitu:

a. Sebelum kehamilan berumur 6 (enam) minggu dihitung dari hari pertama haid terakhir kecuali hal kedaruratan medis.

b. Oleh tenaga kesehatan yang memiliki keterampilan dan kewenangan memiliki sertifikat yang ditetapkan oleh menteri.

c. Dengan persetujuan ibu hamil yang bersangkutan

d. Dengan izin suami, kecuali korban perkosaan

e. Penyedia layanan kesehatan yang memenuhi syarat yang ditetapkan oleh menteri.

Dalam Pasal 75 UU Kesehatan juga dimuat bahwa seorang yang akan melakukan aborsi hanya dapat dilakukan melalui konseling atau penasehat pra atau pasca aborsi. Konselor yang dimaksud disini bertujuan agar ia tidak mengambil keputusan secara emosional, yang barangkali nantinya disesali dan dipastikan memang aborsi merupakan jalan terakhir untuk dilakukan. Koseling yang baik harus menjamin agar keputusan akhir dapat 
dipertanggung jawabkan, dan bebas dari unsur-unsur emosional yang tidak relevan. Idealnya, konselor yang baik selalu akan berusaha agar keputusan akhir memang merupakan keputusan perempuan itu sendiri, dan bukan keputusan yang dipaksakan dari luar. Sebelum aborsi dilakukan pasien benar-benar harus mengadakan konselor yang menyangkut kesehatan fisik dan psikisnya. Dalam mengambil keputusan aborsi pasien harus berkonsultasi dengan dokternya. Karena kehamilan dan aborsi memiliki banyak aspek medis. Karena itu, perempuan hamil membutuhkan informasi dan advis dari orang yang profesional dibidang itu. Jika janin dalam kandungan terdiagnosis dalam keadaan cacat, orang tuanya harus memperoleh informasi cukup lengkap, sebelum mengambil keputusan tentang dilakukannya aborsi atau tidak.

Aborsi yang dimaksudkan dalam UU Kesehatan haruslah aborsi yang aman dan manjamin keselamatan ibu dan kesembuhan pasiennya karena dilakukan oleh para ahli yang memang ahli kandungan dan ditempat yang memang telah sesuai dengan apa yang dimuat dalam peraturan pemerintah. Hal ini sesuai dengan ketentuan Pasal 77 UU Kesehatan No.36 Tahun 2009 yang mengandung pengertian dimana pemerintah wajib melindungi dan mencegah perempuan dari aborsi yang tidak aman, tidak bermutu, tidak bertanggung jawab serta bertentangan dengan norma agama dan undang-undang.

Aborsi yang dilakukan secara sembarangan sangat membahayakan kesehatan dan keselamatan ibu hamil bahkan sampai berakibat pada kematian. Perdarahan yang terus menerus serta infeksi yang terjadi setelah tindakan aborsi merupakan sebab utama kematian wanita yang melakukan.

\section{Abortus Provokatus Ditinjau Dari Kitab Undang-Undang Hukum Pidana (KUHP)}

Pada dasarnya masalah aborsi yang dikualifikasikan sebagai perbuatan kejahatan atau tindak pidana hanya dapat kita lihat dalam KUHP walaupun dalam Undang-Undang No. 36 Tahun 2009 memuat juga sanksi terhadap perbutan aborsi tersebut. KUHP mengatur berbagai kejahatan maupun pelanggaran. Salah satu kejahatan yang diatur di dalam KUHP adalah masalah aborsi kriminalis. Ketentuan mengenai aborsi kriminalis dapat dilihat dalam Bab XIV Buku Kedua KUHP tentang kejahatn terhadap nyawa Khususnya Pasal 346-349. Adapun rumusan selengkapnya pasal-pasal tersebut:

Pasal 299

(1) Barangsiapa dengan sengaja mengobati seorang wanita atau memyuruhnya supaya diobati dengan sengaja memberitahukan atau ditimbulkan harapan, bahwa karena pengobatan itu hamilnya dapat digugurkan, diancam pidana penjara paling lama empat tahun atau denda paling banyak tiga ribu rupiah 
(2) Jika yang bersalah berbuat demikian untuk mencari keuntungan atau menjadikan perbuatan tersebut sebagai pencarian atau kebiasaan atau jika ia seorang tabib, bidan, atau juru obat, pidananya tersebut ditambah sepertiga

(3) Jika yang bersalah, melakukan kejahatan tersebut dalam menjalankanpencarian, maka dapat dicabut haknya untuk melakukan pencarian

Pasal 346

Seorang wanita yang sengaja menggugurkan atau mematikan kandungannya atau menyuruh orang lain untuk itu, diancam dengan pidana penjara paling lama empat tahun.

Pasal 347

(1) Barang siapa dengan sengaja memggugurkan atau mematikan kandungan seorang wanita tanpa persetujuannya, diancam dengan pidana penjara paling lama dua belas tahun

(2) Jika perbuatan itu mengakibatkan matinya wanita tersebut, dikenakan pidana penjara paling lama tujuh tahun

\section{Pasal 349}

Jika seorang tabib, bidan atau juru abat menbantu melakukan kejahatan yang tersebut Pasal 346, ataupun melakukan atau membantu melakukan salah satu kejahatan yang diterangkan pasal 347 dan 348, maka pidana yang ditentukan dalam pasal itu dapat ditambah dengan sepertiga dapat dicabut hak untuk menjalankan pencarian dalam mana kejahatan dilakukan.

Secara singkat dapat dijelaskan bahwa yang dapat dihukum, menurut KUHP dalam kasus aborsi ini adalah:

a. Pelaksanaan aborsi, yaitu tenaga medis atau dukun atau orang lain dengan hukuman maksimal 4 tahun ditambah sepertiga dan bisa juga dicabut hak untuk berperaktik

b. wanita yang menggugurkan kandungannya, dengan hukuman maksimal 4 tahun

c. orang-orang yang terlibat secara langsung dan menjadi penyebab terjadinya aborsi itu dihukum dengan hukuman bervariasi

Dalam KUHP tidak diberikan penjelasan mengenai pengertian kandungan itu sendiri. Dan memberikan arti yang jelas mengenai aborsi dan membunuh (mematikan) kandungan. Dengan demikian kita mengetahui bahwa KUHP hanya mengatur mengenai Aborsi Provokatus Criminalis, dengan demikian semua jenis aborsi dilarang dan tidak diperbolehkaan oleh UU, apapun alasanya.

Pengaturan aborsi provokatus didalam KUHP yang merupakan warisan zaman Belanda bertentangandengan landasan dan politik hukum yaitu melindungi segenap 
bangsa Indonesia dan untuk memajukan kesejahteraan umum berdasarkan Pancasila dan UUD 1945, karena melarang aborsi provokatus tanpa pengecualian. Hal ini dirasa sangat memberatkan kalangan medis yang terpaksa harus melakukan aborsi provokatus untuk menyelamatkan jiwa si ibu yang selama ini merupakan pengecualiaan di luar perundang-undangan.

Ketentuan dalam pasal-pasal KUHP tersebut sangat jelas tidak memberikan peluang dilakukan aborsi, jika pemberlakuan ketentuan pasal tersebut mutlak dan tidak ada alasan apapun. Segala bentuk tindakan aborsi dilarang bagi wanita, tanpa memberikan alternatif untuk menyediakan teknologi kesehatan reproduksi yang aman yang dapat mengurangi resiko kematian wanita hamil, disebabkan adanya resiko penyakit yang berat yang membahayakan jiwa wanita hamil tersebut. Kosekuensinya petugas medis khususnya dokter, bidan dan petugas lainnya dianggap sebagai pelanggar hukum ketika mereka melakukan tindakan aborsi dengan tujuan untuk menyelamatkan jiwa Oleh karena itu perlu diundangkan peraturan yang lebih efektif dan mampu memberikan solusi yang tepat bagi masyarakat serta dapat memberikan peluang pada petugas medis untuk melakukan aborsi dengan ketentuan dan batasan yang telah ditentukan dengan baik.

Dari rumusan pasal-pasal dalam KUHP diatas, dapat ditarik kesimpulan bahwa:

1. Seorang perempuan hamil yang dengan sengaja melakukan aborsi atau ia menyuruh orang lain, diancam hukuman empat tahun penjara.

2. Seseorang yang dengan sengaja melakukan aborsi terhadap ibu hamil dengan tanpa persetujuan ibu hamil tersebut, diancam hukuman penjara 12 tahun, \& jika ibu hamil tersebut mati, diancam penjara 15 tahun penjara.

3. Jika dengan persetujuan ibu hamil, maka diancam hukuman 5 tahun 6 bulan penjara dan bila ibu hamil tersebut mati diancam hukuman 7 tahun penjara.

4. Jika yang melakukan dan atau membantu melakukan aborsi tersebut seorang dokter, bidan atau juru obat ancaman hukumannya ditambah sepertiganya dan hak untuk berpraktik dapat dicabut.

5. Setiap janin yang dikandung sampai akhirnya nanti dilahirkan berhak untuk hidup serta mempertahankan hidupnya. Pada kehamilan yang tidak diinginkan

\section{Hubungan antara KUHP dan UU No. 36 tentang Kesehatan Terhadap Abortus Provocatus}

Apabila ditelaah lebih jauh, peraturan mengenai aborsi provokatus dalam UU. No 36 Tahun 2009 tentang Kesehatan Dan dalam Pasal 299 dan 346-349 KUHP kedua peraturan tersebut berbeda satu sama lain. KUHP mengenal larangan aborsi provokatus tanpa kecuali, 
termasuk aborsi provokatus medicanalis dan aborsi provokatus tanpa kecuali, temasuk aborsi provokatus medicinalis dan aborsi provokatus therapeuticus. Tetapi UU No. 36 Tahun 2009 justru memperbolehkan terjadi aborsi provokatus medicalis dengan sepesifikasi therapeutics.

Dalam konteks hukum pidana, terjadilah perbedaan antara peraturan perundangundangan yang lama (KUHP) dengan peraturan perundang-udangan yang baru. padahal peraturan perundang-undangan disini berlaku asas lex posteriori derogat legi priori". Asas ini beranggapan bahwa jika diundangkan peraturan baru dengan tidak mencabut peraturan lama yang menagatur materi yang sama dan keduanya saling bertentangan satu sama lain, maka peraturan yang baru itu mengalahkan atau melumpuhkan peraturan yang lama (Siregar1994, :53). Dengan demikian, Pasal 75 UU No. 36 Tahun 2009 yang mengatur tentang aborsi provokatus medicinalis tetap dapat berlaku di Indonesia meskipun sebenarnya aturan berbeda dengan rumusan aborsi provokatus criminalis menurut KUHP.

Berlakunya asas lex posteriori derogat legi priori sebenarnya merupakan salah satu upaya pemerintah untuk mengembangkan hukum pidana Indonesia. Banyak aturan-aturan KUHP yang dalam situasi khusus tidak relevan lagi untuk diterapkan pada masa sekarang ini. Untuk mengatasi kelemahan KUHP tersebut Pemerintah mengeluarkan UU Kesehatan dengan harapan dapat memberikan suasana yang kondusif bagi dinamika masyarakat Indonesia pada masa sekarang ini.

Asas lex posteriori derogat legi priori merupakan asas hukum yang berkembang di seluruh bidang hukum. Fungsinya dalam ilmu hukum ( khususnya hukum pidana) hanya bersifat mengatur dan eksplikasitif ( menjelaskan ). Asas ini berfungsi untuk menjelaskan berlakunya Pasal 75-78 ketika harus dikontfrontasikan dengan pasal-pasal KUHP yang mengatur masalah abortus provokatus.

Melihat rumusan Pasal 75 UU No. 36 Tahun 2009, tampaklah bahwa dengan jelas UU No. 36 Tahun 2009 melarang aborsi, kecuali untuk jenis aborsi provokatus therapeuticus. Dalam dunia kedokteran aborsi provokatus medicalis dapat dilakukan jika nyawa si ibu terancam bahaya maut dan juga dapat dilakukan jika anak yang akan lahir diperkirakan mengalami cacat berat dan diindikasikan tidak dapat hidup diluar kandungan, misalnya janin menderita kelaianan ectopiakordalis, rakiskisis maupun anensefalus.

Dalam UU Kesehatan No. 36 Tahun 2009 juga telah diatur mengenai aborsi yang dilakukan oleh korban perkosaan yang diindikasikan dapat menyebabkan trauma psikis bagi si ibu. Jika dalam UU Kesehatan yang lama tidak dimuat secara khusus mengenai aborsi terhadap korban perkosaan sehingga menimbulkan perdebatan dan penafsiran diberbagai 
kalangan, dengan adanya UU Kesehatan yang baru maka hal tersebut tidak diperdebatkan lagi mengenai kepastian hukumnya karena telah terdapat pasal yang mengatur secara khusus.

Berdasarkan uraian tersebut diatas dapat disimpulakan bahwa Pasal 75 UU No. 36 Tahun 2009 tentang kesehatan mengatur mengenai aborsi provokatus yang diperbolehkan di indonesia, yakni aborsi provokatus atas indikasi medis atau dalam bahasa kedokteran disebut sebagai aborsi provokatus medicalis. Lebih lanjut ditegaskan lagi bahwa indikasi kedaruratan medis, yang dimaksud adalah sesuatu kondisi benar-benar mengharuskan diambil tindakan medis tertentu demi penyelamatan si ibu. Jadi yang perlu ditekankan adalah indikasi kedaruratan medis itu merupakan upaya untuk menyelamatkan jiwa si ibu janin memang tidak dimungkinkan untuk hidup diluar kandungan karena cacat yang berat.

Suatu hal yang merupakan kelebihan dari pasal-pasal aborsi provokatus UU No. 36 Tahun 2009 adalah ketentuan pidananya. Ancaman pidana yang diberikan terhadap pelaku aborsi provokatus criminalis jauh lebih berat daripada ancaman pidana sejenis KUHP. Dalam Pasal 194 UU No. 36 Tahun 2009 pidana yang diancam adalah pidana penjara paling lama sepuluh tahun dan pidana denda paling banyak Rp. 1.000.000.000.000 (satu milyar). Sedangkan dalam KUHP, pidana yang diancam paling lama hanya 4 tahun penjara atau denda paling banyak tiga ribu rupiah (Pasal 299 KUHP), paling lama empat tahun penjara (Pasal 346 KUHP), paling lama dua belas tahun penjara (Pasal 347 KUHP), dan paling lama lima tahun enam bulan penjara (Pasal 348 KUHP).

Ketentuan pidana mengenai aborsi provokatus ciminalis dalam UU No. 36 Tahun 2009 dianggap bagus karena mengandung prevensi umum dan prevensi khusus untuk menekan angka kejahatan aborsi kriminalis. Dengan merasakan ancaman pidana yang demikian beratnya itu, diharapkan para pelaku aborsi criminalis menjadi jera dan tidak mengulangi perbuatannya, dalam dunia hukum hal ini disebut sebagai prevensi khusus, yaitu usaha pencegahan agar pelaku aborsi provokatus criminalis tidak lagi mengulangi perbuatannya. Sedangkan prevensi umumnya berlaku bagi warga masyarakat karena mempertimbangkan baik-baik sebelum melakukan aborsi daripada terkena sanksi pidana yang amat berat tersebut. Prevensi umum dan prevensi khusus inilah yang diharapkan oleh para pembentuk UU dapat menekan seminimal mungkin angka kejahatna aborsi provokatus di Indonesia.

\section{Perbandingan Pandangan (Pers pektif) Terhadap Aborsi Antara UU No.36 Tahun 2009 Tentang Kesehatan, KUHP dan HAM}

Indonesia sebagai negara yang ikut menandatangani kesepakatan ICPD di Kairo tahun 1994, Konferensi wanita Beijing tahun 1995 serta Millennium Development Goal (MDGs) tahun 2000, selayaknya pemerintah memberi perhatian serius terhadap masalah tingginya 
Angka Kematian Ibu (AKI) dan perlindungan terhadap perempan dari resiko kematian akibat persalinan dan terutama aborsi tidak aman. Pengakuan terhadap hak reproduksi perempuan terlihat dalam deklarasi ICPD yang dikukuhkan dengan deklarasi Beijing tahun 1995 dan Konverensi Dunia ke IV tentang Perempuan tahun 1996 yang menyebutkan bahwa :

a. Hak individu untuk menentukan kapan akan mempunyai anak, berapa jumlah anak, dan berapa lama jarak tiap kelahiran anak.

b. Hak untuk mendapatkan pelayanan yang berkaitan dengan fungsi reproduksinya.

c. Hak untuk mendapatkan informasi, komunikasi dan edukasi yang berkaitan dengan hak reproduksi, dan

d. Hak melakukan kegiatan seksual tanpa paksaan, diskriminasi, dan tanpa kekerasan.

Dari uraian diatas maka penulis akan memaparkan aborsi dari perspektif tiga peraturan hukum yaitu KUHP, UU No.36 Tahun 2009 tentang kesehatan dan Hak Azazi Manusia. Dari tiga perspektif yang berbeda tersebut pada kondisi normal terhadap abortus provocatus yang tidak memiliki alasan pembenar dilakukannya ketiga aturan hukum tersebut mempunyai pandangan yang sama yaitu, Menurut KUHP abortus provocatus merupakan tindakan pidana yang dapat dikenakan sanksi pidana, begitu juga halnya dengan UU kesehatan juga tidak membenarkan tindakan abortus provocatus tanpa ada alasan pembenar, sementara dari sudut pandang HAM abortus provocatus di anggap sebagai pelanggaran terhadap hak azazi manusia karena dalam UU hak azazi manusia pasal 53 (1) No. 39 tahun 1999 disebutkan bahwa setiap anak sejak dalam kandungan, berhak untuk hidup dan meningkatkan taraf hidupnya. Anak dalam kandungan yang dimaksud adalah janin yang nantinya akan tumbuh menjadi anak dan berkembang selayaknya manusia. Janin merupakan awal kehidupan yang harus dihormati oleh setiap manusia dan dijaga karena janin nantinya akan tumbuh dan berkembang menjadi manusia yang kelak juga akan menghasilkan hal yang sama. Jadi berapapun usia janin, berapapun dikatakan usia awal kehidupan janin, janin har us tetap dipertahan hidup sepanjang tidak membahayakan kondisi sang ibu dan memang dapat terlahir kedunia tanpa mengancam nyawa ibu dan janin.

Pandangan terhadap abortus provocatus atau aborsi menjadi berbeda manakala terdapat keadaan yang memaksa untuk dilakukannya aborsi. Sebagai alasan yang dibenarkan oleh peraturan perundang-undangan. Meskipun sebagaimana telah dijelaskan diatas bahwa KUHP tidak memberikan Pengecualian Terhadap tindakan Aborsi dalam keadaan apapun. Sementara UU kesehatan memberikan jalan keluar manakala terdapat alasan pembenar dilakukannya tindakan aborsi sebagai jalan terbaik yang harus ditempuh. Sementara aturan dalam Hak Azazi manusia masih menyisakan perdebatan panjang yang belum menemukan titik temu 
antara dua kutub pemikiran yang sering disebut pro-choice sebagai pihak yang memberikan kebebasan kepada wanita untuk melakukan aborsi, atau dengan kata lain kelompok ini mendukung aborsi yang dilakukan oleh wanita, sementara dipihak lain kelompok yang mengatasnamakan dengan pro-life tidak menyetujui aborsi yang dilakukan oleh wanita dalam keadaan apapun.

Dua kutub pemikiran ini nampaknya berangkat dari titik pandang yang saling bertentangan. Mereka yang menolak tetap berpandangan negara seharusnya tidak terlibat dalam soal kesehatan reproduksi yaitu aborsi yang merupakan wilayah pribadi. Dengan adanya peran negara untuk memasuki wilayah ini dapat memperluas campur tangan negara kedalam wilayah pribadi anggota masyarakat dan berpotensi negative terhadap kebebasan dan perkembangan demokrasi. Dukungan dan penolakan RUU Kesehatan mengenai aborsi ini berangkat dari paradigma yang berbeda. Pendukung adanya pelegalan aborsi sebagian berasal dari LSM kesehatan yang beranggapan bahwa masalah aborsi harus dilihat sebagai isu kesehatan reproduksi bukan sebagai isu kriminalitas.

\section{KESIMPULAN}

Menurut penulis, timbulnya perbedaan terhadap aborsi dalam UUK, KUHP dan HAM merupakan konsekuensi logis akibat dari sudut pandang dan nilai filosofis dari masingmasing norma hukum tersebut yang berbeda. UUK dan KUHP merupakan aturan perundangundangan dalam bingkai hukum pidana sebagai hukum publik yang berusaha menciptakan ketertiban umum dengan membuat aturan hukum yang dapat mencegah terjadinya tindakan pidana yang dinilai tidak sesuai dengan norma hukum yang berlaku di Indonesia. Sedangkan HAM merupakan norma hukum yang berlandaskan pada hukum kodrati manusia yang harus dipelihara karena dinilai sebagai sesuatu yang melekat (inheren) dengan eksistensi manusia dalam hal ini wanita.

Jika ditinjau dari perspektif yuridis yang lain maka antara hukum pidana dan HAM memposisikan Wanita dalam kasus aborsi ini dalam objek dan subjek hukum yang berbeda. Hukum pidana menempatkan wanita sebagai subjek hukum dan anak atau janin sebagai objek hukum. Sementara HAM menempatkan Wanita dan anak sama-sama sebagai objek hukum yang harus dilindungi, HAM menempatkan wanita dan janin atau anak dalam kandungan sebagai korban bukan sebagai pelaku aktiv dari tindakan aborsi.

Pengguguran kandungan atau yang biasa masyarakat kenal sebagai aborsi, merupakan praktek yang selama ini masih dilakukan oleh mereka yang tak menginginkan kelahiran si janin yang dikandungnya. Aborsi dapat terjadi baik akibat perbuatan manusia atau 
(abortuisprovokatus) maupun karena sebab-sebab alamiah, yakni terjadi dengan sendirinya, dalam arti bukan karena perbuatan manusia (aborsispontanus). Aborsi yang terjadi karena perbuatan manusia dapat terjadi baik karena didorong oleh alasan medis, misalnya karena wanita yang hamil menderita suatu penyakit dan untuk menyelamatkan nyawa wanita tersebut maka kandungannya harus digugurkan (aborsi provokatus therapeutics atau bisa disebut aborsi therapeuticus). Pada beberapa peraturan perundang-undangan yang berlaku di Indonesia dan dikaitkan dengan keyakinan yang dipegang teguh oleh masyarakat, terdapat penafsiran yang berbeda mengenai aborsi. Jika menilik apa yang terdapat UndangUndang tentang Kesehatan, aborsi dapat dilakukan namun dengan syarat-syarat tertentu, hal tersebut tentunya kan berbeda dengan pandangan yang terdapat dalam Undang-Undang tentang HAM, Kitab Undang-Undang Hukum Pidana, dan juga dalam hukum islam itu sendiri.

\section{REFERENSI}

Achadiat Chrisdiono M., 2006. Dinamika Etika dan Hukum Kedokterran, Jakarta: Buku Kedokteran EGC.

Bertens K. 2002, Aborsi Sebagai Masalah Etika . Jakarta: Grasindo.

Chandra, Lilien Eka, 2006. Tanpa Indikasi Medis Ibu, Aborsi sama dengan Kriminal.Lifestyle

http:// media informasill.com/2012/04/pengertian-definisi-analisis.html, pada tanggal 8 November 2013, pukul 17:00 WIB.

Ilyas, Amil, 2012. Asas-Asas Hukum Pidana, Yogjakarta:Rangkang Education.

Kusmaryanto, 2002.Kontroversi Aborsi, Jakarta: Gramedia Widiasarana Indonesia.

Nasution, Bahder Johan, 2008. Metode Penelitian Ilmu Hukum, Bandung: Mandar Maju.

Notoatmodjo, Soekidjo,2010. Etika Dan Hukum Kesehatan, Jakarta: Rineka Cipta.

Moeljatno, 2002. Asas-Asas Hukum Pidana, Jakarta: Rineka Cipta.

Rukmini, Mien, 2002. Laporan Akhir Penelitian Tentang Aspek Hukum Pelaksanaan Aborsi Akibat Perkosaan, Badan Pembinaan Hukum Nasional Departemen Kehakiman dan $H A M$, Jakarta.

Saleh, Ruslan, 1983. Stelsel Pidana Indonesia, Jakarta: Aksara Baru.

Siregar, Hasnil Basri,, 1994. Pengantar Hukum Indonesia, Medan: Penerbit Kelompok Studi Hukum dan Masyarakat Fakultas Hukum USU. 
Rustam: Analisis Yuridis Terhadap Tindakan Aborsi Dalam Perspektif...

Surayin, 2000. Kamus Umum Bahasa Indonesia Bandung: Yrama Widya.

Utrecht,E.,1958. Hukum Pidana I, Jakarta:Universitas Jakarta 